\title{
Human Psychology (fitrah) from Islamic Perspective
}

\author{
Ali Muhamad Bhat ${ }^{1}$ \\ 1/slamic Research Academy, Brakpora Anantnag Jammu and Kashmir, India \\ Email: alimohd1265@gmail.com
}

\begin{abstract}
:
Education is crucial for all mankind. It is achieved to perfect all aspects of human's life and to attain perfection in one's life. To achieve true education, one must keep knowledge on the philosophy and objectives of education put forth by different religions and civilization but more importantly as stipulated in the Al-Quran and Sunnah. These sources help in the operative formulation of generating the complete growth of individual with integrated, balanced, and collective personality. The principal task of education is, to nurture the personal growth of a human being. It is through this development of the individual and the preservation and transmission of culture that both the individual and society attains a quality of life. A good man is not necessarily a complete man. No one can be stared as a complete human because there is no end to the growth of human personality. A wide knowledge of many subjects helps in the growth of personality (psychology) provided a man knows how to modify behavior and knows how knowledge and actions are integrated into a broad, total framework of life. This issue has been taken into hand to provide an insight from Islamic perspective for a broad continuum of personality development or what in contemporary era is called human psychology. An analytical approach is adopted to search the sources which contain information related to human nature in order to justify that religion has a strong voice to help humans to cognize the role of Islamic Psychology in human development.
\end{abstract}

Keywords: Fitrah, Nafs, Wara, Lafaz mushtarak, Ibā dah, Qalb, Psychology.

\section{A. INTRODUCTION}

The Islamic concept of human nature is an all-encompassing, rooted with a thought that man is born on "'fitrah"'" nature which is later on influenced by the prevailing circumstances. The word "fitrah" comes from the Arabic radicals' fa ta ra, the verbal noun being fatrun. The root action means, he cloves, split, slit, rent or cracked it. The usage of the first form fatarahu (He created it), i.e. mean in its complete pure form without any ill will and ill intention. Thus fatiru's-samâwât, the Originator or Creator of the heavens (Ibn Manzûr, 1988: 1108-1109; cf. al-'Arabi, 1984: 2415; cf. Lane, E. W., 1972: 397). The second form, fattara(hu) (verbal noun taftir), denotes repetition, muchness and frequency of the root action which means, as we saw, he cloves, split, slit, rent or cracked it. ${ }^{1}$

1 This repetition also applies to the $7^{\text {th }}$ form verb infatara, $5^{\text {th }}$ form tafattara and the $1^{\text {st }}$ form fatara, e.g. idha's-samâ'unfatarat 'When the heaven shall be cleft', (Qur'ân 82:1), and yakadu's- 
The Islamic concept of Human nature is one which is fashioned for upbringing of one's life and help others and led them to finality of life in a successful manner. Among all creations in the heaven and earth, only human being is raised unto the highest summit to be called Ashraf alMakhlöqat; "We have indeed created man in the best of moulds (fitrah)" (Yusuf, 1989).

"Fitrah" is also concomitant with core of Islam and being born as a Muslim denotes he confirms the reality of Allah by his nature. So "fitrah" is viewed in respect to. It is the natural or divine makeup with which the child is created in his mother's womb, whereby he is capable of accepting the religion of truth (Rashad, 1991: 190). In psychological manner man always tilt towards inner consciousness and gets solace by it, in this manner "fitrah" means bring up to religion. Allah bless him and grant him peace, taught a man to repeat certain words when lying down to sleep, and said: 'Then if you die that same night, you die upon the "fitrah" (in the true deen). 'Also by the saying: 'The paring of the nails is of the "fitrah" (i.e. of the deen)' (Ibn Manzûr, 1988: 1109-10).

\section{B. METHODS}

An analytical approach is adopted to search the sources which contain information related to human nature in order to justify that religion has a strong voice to help humans to cognize the role of Islamic Psychology in human development.

\section{RESULT AND DISCUSSIONS}

It is clear, from the Qur'an and hadith that every child is born with a uncontaminated nature, as a Muslim. Islam recognises that all children, whether born of believing or unbelieving parents, go to Paradise if they die before attaining the age of discretion. In the context of the hadith, according to Abû Haytham, "fitrah" means to be born either prosperous or unprosperous in relation to the soul:

'And if his parents are Jews, they make him a Jew, with respect to his worldly situation; [i.e. with respect to inheritance, etc.] and if Christians, they make him a Christian, with respect to that situation; and if Magians, they make him a Magian, with respect to that situation; his situation is the same as that of his parents until his tongue speaks for him; but if he dies before his attaining to the age when sexual maturity begins to show itself, he dies in a state of conformity to his preceding natural constitution, with which he was created in his mother's womb' (Ibn Manzûr, 1988: 1109; Lane, 1972: 2415-16).

Imâm Nawawî defined "fitrah" as the unconfirmed state which exists until the individual consciously acknowledges his belief. Hence, if a child were to die before he attains discretion he would be on of the inmates of Paradise. This view applies to the children of polytheists as well, and is supported by the above-quoted hadith. The legal implication of this hadith is that all children are born pure, sinless and predisposed to belief in one God; moreover they are of the inmates of Paradise; however, if their parents are non-Muslims, the religion of their parents will be applicable to them in this world (Ta'arud 1981: 382-3).

Islam is also called deen al-"fitrah", the religion of human nature, because its laws and its teachings are in full harmony with the normal and the natural inclination of the human "fitrah" to believe in and submit to the Creator as stated in Qur'an:

samâwâtu yatafttarna minhu 'The heavens almost become repeatedly rent in consequence thereof', (Qur'an 19:92), and tafatarat qadamahu 'his feet became cracked'. 
'And who is better in obedience (in deen) than he who resigns himself to Allah?' (Qur'an 4:125)

'There shall be no compulsion in obedience (deen).' (Qur'ân 2:256)

Ad-deen implies religion in the widest sense of the word, embracing both the practical aspects of the acts of worship and ordinary transactions of life, and the teachings of religion; and it is a name for that whereby one serves Allah.

'Truly, the religion (deen) in the sight of Allah is al-Islam.' (Qur'ân 3:19)

Lane defines it, as it means principally the religion of al-Islam. The synonyms of ad-deen are ashShari'ah (the law), tawhid (Oneness of Allah) and wara' (caution). It is derived from the verb dana, meaning 'he had indebted'. However, al-Attas, explained it in a more elaborated and significant "because man is indebted to Allah for his existence and sustenance. The believer will realise that his psychology acknowledged Allah in pre-existence period, and has to put all his actions according to the debated he owned, must return it in life by service and submission to Allah. This return implies a return to man's inherent spiritual nature, to his "fitrah". By his acquiescent Allah in such a manner, man in fulfilling the purpose of his creation and existence.

'I have not created the Jinn and man but that they should serve Me (li ya'budûnî).' (Qur'an 51:56)

Al-Attas laconically explains the connection between submission, "fitrah" and deen as follows:

'When we say that such a man is fulfilling the purpose for his creation and existence, it is obvious that that man's obligation to serve God is felt by him as normal because it comes as a natural inclination on the man's part to do so. This natural tendency in man to serve and worship God is also referred to as deen ... here in the religious context it has a more specific signification of the natural state of being called "fitrah". In fact deen also means "fitrah". It is the pattern according to which God has created all things... Submission to it brings harmony, for it means realisation of what is inherent in one's true nature; opposition to it brings discord, for it means realisation of what is extraneous to one's true nature' (Al-Attas, 1985: 57-58).

This dignified nature provided human beings higher archival status among the creations called a sound psychological being and makes him superior to angels and other luminescent creations like the sun, moon, stars, etc. His dignified character is further explained in Quran as:

We have honoured the sons of Adam; provide them transport on land and sea; given them for sustenance things good and pure; and conferred on them special favours above a great part of our creation. (Qur'ān, Al-Isrā':70)

Having achieved a noble position in the sight of Allah does not guarantee man to be in that position forever. As explained in Sū rah al-Tīn, verse: 5, man will fall from the honoured position given by Allah when he transgresses the limits. As such, achieving the honor or disgrace in the sight of Allah, is a choice left to man to decide (Razak, 1997: 171-173).

Man has been given the exalted position and was authorized by the title in the Holy Qur'an as the Khalā fatullah fi al-ard (Allah's vicegerent on earth). The exact discourse happened between Allah and the angels. The ins and outs of dispute of angels can be well assumed from the following verse of Sū rah Al-Baqarah: 
Behold, thy Lord said to the angels: "I will create a vicegerent on earth." They said: "Wilt Thou place therein one who will make mischief therein and shed blood? - whilst we do celebrate Thy praises and glorify Thy holy (names)?" He said: "I know what ye know not". (Al-Baqarah: 30)

The exegesis on the above verse explains that the angels forecasted some negative attitudes of man, while Allah, the All Wise saw many of the positive things that man is capable of performing on earth (Asad, 1980: 102-104). Among the favors that man attained from Allah were, authority, freedom of action, intelligence, etc. These achievable gifts need to be used for positive ends, Afzalur Rahman (1988) explains:

"He was to be totally independent and autonomous in his sphere of work on the earth and would be well-equipped with knowledge so that he could discover the secrets of the Universe through study, research and experience, learn to explain the forces of nature for his benefit, and gain mastery over them according to his own requirements and plan" (Rahman, 1988: 9-10.).

The title Khaliffah Allah place man in an honored position as deputy; administrator; representative, etc. on earth and bestows him position to confer all powers and authority to rule, manage and preserve the earth as God's representative with clear instructions provided by Qur'an and Sunnah and Islamic legacy. This position does not place man as sole sovereign of the world. He devolves all his actions as a subordinate of God clearly following his instructions. Al-Maududi, in Tafheem ul-Qur'an, expounds that "man's status as the Khaliffah Allah does not make him the master of the universe, but only as a deputy who is allowed to exercise the delegated powers given to him by Allah the all Supreme." (Al-Maududi, Abu A'la, 1992, 66-68). As per human fitrah one has to surrender his will to his creator in order to achieve the aim of life and to remain away from hegemonic character of selfishness. In Islam, man is born with the Fitrah (primordial nature) ( atTabataba'i, 56-58). Al-Fitrah in the Arabic language renders several different meanings that reveal the many positive and interesting dimensions of human nature (Izzati, 2002: 93-96). One meaning to the word Al-Fitrah is explained as "Masoom anil Khata" means without any tint of sin. This concept helps man to overcome the human hegemony of rational argument the doctrine of "Original Sin" as espoused in the Christianity (Geisler \& Saleeb, 2002: 45). But Al-Fitrah philosophy is explained in the Holy Qur'an, in relation to man's existence, "So set thou face steadily and truly to the faith: (established) Allah's handiwork according to the pattern on which He has made mankind: no change (let there be) in the work (wrought) by Allah... "(Al-Qur'ā n, Al-Rū m: 30).

Human nature gets influenced as per circumstances because of the tendency which prevails due to his dual nature; body and spirit $(R \bar{u} h)$.

In Islam, "tendency" may bear similarity to the term "fitrah". According to the Kamus Dewan, the term "fitrah" is a natural disposition or tendency (Kamus Dewan, 1996). It is also defined as religious sentiment. From an etymological perspective, the word fitrah comes from the Arabic word fitrah, which means "to originate" tendencies from birth "disposition" and/or "instinct". The al-Qur'ā $n$ mentions the concept of fitrah many times with a pronouncement of lafazmushtarak that holds a variety of connotations (al-Mucāsirah, 2000), for example origins in the word Fațara, and linguistic studies have given even more possible originating words such as Fā țir, and fitrah (Saliba, 1971: 65) which means "Creator" or "He who creates".

Sayyid Qutb (1906M - 1966M) thought that the meaning of the verse above clarified the view of Islam towards mankind in all aspects. Man's habits, potentials and tendencies are twodimensional, meaning they can lean toward one way or another. The nature of his creation as a 
being made from clay and a soul breathed into him by the Almighty Allah makes him the possessor of the same potential for good or bad, guidance or deviance. Man is capable of distinguishing between good and bad, and is also capable of directing himself to do either in the same magnitude (Qutb, 1979: 3917).

These potentials can however be influenced by the patterns in which man is raised, the level of his education and his life experiences. H. M. Arifin had produced several verses from the al-Qur'ā $n$ and al-Hadith as well as the interpretations of the ulama regarding them, which triggered other views that leaned towards the concepts of nativism and empiricism (Musa, 1953: 98). The body has tendency towards lavish activities whereas Ruh has complete inclination towards its inert nature. But most of the times the worldly desires develop its influence on the spirit because of the freedom given to human beings. Nevertheless, Allah exalted to him on the highest throne and shaped him into best of the creatures (Qutb, 1983: 338-339). The Holy Qur'an explains that after creating Adam (P.B.U.H.), Allah breathed into him His spirit: "Behold! Thy Lord said to the angels: "I am about to create man, from sounding clay form mud molded into shape; "When I have fashioned him (in due proportion) and breathed into him of My spirit, fall ye down in obeisance unto him" (Al-Qur'ān, Al-Hijr: 28-29). As such, all human beings who are the progeny of Adam (P.B.U.H.) are made up of two elements; the physical body, which represents clay, is mortal, and the spirit, which is immortal that leaves the body upon death of an individual. The most honored creation of Allah, is also assigned with the Amā nah (trust) from Allah;

"We did indeed offer the Trust to the Heavens and the Earth and the Mountains; but they refused to undertake it, being afraid thereof: but man undertook it- he was indeed unjust and foolish". (AlQur'ā n, Al-Ahzā b:72;)

Amā nah has various meanings which can be referred to reason, intellect or the faculty of volition. Not only has this but also meant the power and authority given to man through the office of vicegerency. Amānah could also mean the sum total of all the decrees, commands (Amr) and prohibitions (Nahy) present in the Sharīah (Asad, 1980: 906).

Before creation the human nature was completely embedded with all the knowledge necessary for the life cycle and the knowledge which can save him from all lavish and inhuman actives. He was also given knowledge of vices in order to remain away from wrong doings. In this regard from human beings Mīthā $q$ (covenant)has been taken to full fill his duty towards Allah as his Abd (servant) Through this covenant, humanity as a whole has accepted Allah to be their Lord and Cherisher while they were in the form of spirits in ' $\bar{A}$ lam Al-Arwā $h$ (in the realm of the spirits).

This contract between man and his Lord has been made long before he was born into this world. The Holy Qur'an explains about this contract in Sū rah Al-A'rā f:

When thy Lord drew forth from the Children of Adam from their loins their descendants, and made them testify concerning themselves, (saying): 'Am I not your Lord (Who cherishes and sustains you)?'- They said: 'Yea! We do testify!' (This), lest Ye should say on the Day of Judgement: 'Of this we were never mindful'. (Al-A'rā $f: 172)$

According to Muhammad Assad, the "bond with God" (conventionally translated as "God's covenant") apparently refers here to man's moral obligation to use his inborn gifts - intellectual as well as physical in the way intended for them by God. The "establishment" of this bond arises from the faculty of reason which, if properly used, must lead man to a realization of his own weakness and dependence on a causative power and, thus, to a gradual cognition of God's will with 
reference to his own behaviour. This interpretation of the "bond with God" seems to be indicated by the fact that there is no mention of any specific "covenant" in either the preceding or the subsequent verses of the passage under consideration. The deliberate omission of any explanatory reference in this connection suggests that the expression "bond with God" stands for something that is rooted in the human situation as such, and can, therefore, be perceived instinctively as well as through conscious experience: namely, that innate relationship with God which makes Him. According to the Qur'an, the ability to perceive the existence of the Supreme Power is inborn in human nature (fitrah); and it is this instinctive cognition - which may or may not be subsequently blurred by self-indulgence or adverse environmental influences - that makes every sane human being "bear witness about himself" before God (Asad, 1980: 331).

Man being the vicegerent of Allah was also elevated in his stature and position when he was taught Al-Asmā' (attributes of Allah/ the beautiful names of Allah) by God Almighty Himself. The reference to this, man as the recipient of 'the names' has been stated in the following verse:

And He taught Adam the names of all things; then He placed them before the angels, and said: "Tell Me the names of these if ye are right." They said: Glory to Three: of knowledge we have none, save what Thou has taught us: in truth, it is Thou who art perfect in knowledge and wisdom" (Al-Qur'ā n, Al-Baqarah: 31-32; Ali, 1989).

Abdullah Yusuf Ali (1989) says:

The names of things: "according to commentators means the inner nature and qualities of things, and things here would include feelings. The particular qualities of feelings which were outside the nature of angels were put by Allah into the nature of man. Man was thus able to love and understand love, and thus plan and initiate, as becomes the office of vicegerent (Note no. 48:24) (Ali, 1989).

According to Langgulung (1986, 1991a \& 1991b), Al-Asmā' mentioned in verse 31 of Al-Baqarah refers to Al-Asmā' Al-Husnā (the 99 Beautiful Names of Allah) mentioned in the Holy Qur'an (alNu'mā n, 1997: 74-75). These beautiful names represent the attributes of Allah given to man as potentials that need to be developed and actualized in the life of an individual Muslim. By doing so, the individual will be able to fulfil and perform his duties and obligations that will turn out to be ' $I b \bar{a}$ dah (acts of worship done in seeking the good pleasure of Allah). The word Al-Asmā' and described it as colossal and unconstrained potential of knowledge, if understood in proper order would guide humans in all walks of life. He is of the view that the knowledge given to the angels is inadequate, restricted and specific, whereas man is granted not only with knowledge but also the aptitude to produce new knowledge for the achievement of heights and get nearness to god for the satisfaction of the soul (Ansari, 1992).

In free will human can be good or evil as per the natural application of the mental ability as instructed in the Holy Qur'an. "We showed him the way; whether he be grateful or ungrateful (rests on his will)" (Al-Qur'ā n, Al-Insā n: 3; Ali, 1989). An analogous avowal on the freedom of choice has also been mentioned in Sū rah al-Balad, verses 8-10; "Have We not given him two eyes, and a tongue and two lips, and shown him the two highways (of good and evil)" (Ali, 1989).

Form the human tendency point of view as mentioned in the Holy Qur'an, about the forgetful nature of man in context to the story of Adam (P.B.U.H.). He ate the fruit of the forbidden tree together with his companion Hawwah (P.B.U.H.) in the paradise. This incident has been mentioned in Sū rah Tā hā, verse 115, "We had already, beforehand, taken the covenant of Adam, 
but he forgot: and We found on his part no firm. On the contrary, when man develops and portrays the adorable and godly attributes he becomes an angelic as well as a godly individual who qualifies himself in gaining Allah's good pleasure. It has been planned in the Holy Qur'an and Hadith that such an individual will taste happiness in this world and an everlasting pleasure in the hereafter (Abbas, 1997).

Human nature gets influenced not only by religio-political biasedness' but also by the variation in the spiritual content of the societies. One marked dissimilarity that separates Islamic psychology from the Western schools of psychology is spiritual dimension in human nature, in addition all other magnitudes emphasized by Western psychology. The main source of spiritual content in Islamic psychology is Holy Qur'an which fashion all his ethical behavior and religious obligations also deliver facts on man's physical and biological nature. According to Ansari, the core of Qur'anic message is the innate nature of humanity and facts on this dimension of man expounds that man is not only a social and moral being but also as spiritual being (Ansari, 1992: 5-11).

To the Western mainstream psychology, the investigation on the spiritual dimension of man is never considered as a matter of great concern for the simple reason that the human spirit or soul is a thing unseen. They study human psychology within the content of human mind and heart and paid attention towards heart. Since for them spirit is immaterial, it cannot be subjected to any empirical analysis. On the other hand, for the Muslim scholars this unseen dimension of human nature forms a part and parcel of their fundamental beliefs and principles. One among the many verses that states about the belief in the unseen is this verse: "Who believe in the Unseen, are steadfast in prayer and spend out of what We have provided for them". (Al-Baqarah: 3).

At the time of the rise of Islam it was natural that the early Muslims dealt with the teaching of the new religion-the Islamic way of life-and with the establishment of the new state, rather than paying regard to the problem of how to approach the study of nature and its phenomena. Therefore, the early Muslims could not leave us a particular book on the methodology for the study of nature. This is of course not to say that they did not express their views about nature at all. In the Islamic world, early ideas on man, human nature, his behaviour, characteristics and personality have been explored and explained by scholars who were either philosophers, Sufis or scientists. In conceptualizing their ideas on man, these scholars mainly used the Holy Qur'an and Hadith as their primary sources. Further using numerous descriptions and specific ideas found in the authentic books of Islam, Classical scholarship also made use of some logical and philosophical ideas on human nature developed by the Greek philosophers (Langgulung, 1981).

Nevertheless, it is praise worthy that whatever ideas they borrowed from Greek philosophy were first scrutinized and brought under the scale of empirical study of Islamic knowledge in order to judge their authenticity and assimilated, accommodated and integrated within the existing knowledge they have perceived through the Islamic sources. Among these scholars put forth their ideas to hangout the nature of humans prescribed by Islam. Al-Kindi (real name is Abu Yusuf Ya'qub Ibn Ishaq al- Sabbah Ibn Imran Ibn Ismail Ibn al-Ashdath Ibn Qais Al-Kindi) (188-260H I 803-873) is considered to be the first philosopher and the pioneer of pure philosophy in the Muslim world (Atiyeh, 1985: 56). According to Al-Kindi, the human soul is a simple, indestructible divine entity which derives its essence from Allah. Its union with the body is on a transitory period. In AlKindi's notion, the human body is an impediment to the growth of the soul. Therefore, as and when it separates from the body it can gain greater heights of consciousness and knowledge. It is after the physical death of the human body that the soul returns to the world of intellect, the world of Allah and unites with it (Qadir, 1991). He further divides the human soul into three parts; the intellectual (al-quwwah al-'aqliyyah), the passionate (al-ghadabiyyah) and the concupiscence (as- 
shahwaniyyah). Analogically he describes the intellectual part of the soul as the charioteer and the other two parts as horses that pull the chariot. In Al-Kindi's opinion, the passionate and concupiscence parts of the soul will neither want to align nor to cooperate with the intellectual part to strive for a higher purpose in life (Hunt, 1994: 216) Al-Kindi believes that man has the tendency and propensity to do good due to the fact that he has a divine origin while as man's evil desires and behaviour are caused by the triumph of passion over reason. On the other hand, he also believes that the faculties of reason and knowledge of the soul has the potential to safeguard the divine nature of man from the onslaught of the sense perceptions. He is of the opinion, that man should not disregard all efforts that need to be taken to protect him against all vicious acts to rise to the highest ends of human virtue. Abu Nars Muhammad Ibn Muhammad Ibn Tharkan Ibn Uzlagh Abu Nas Al-Farabi was born in Khurasan $260 \mathrm{H} / 874$ and passed away in $339 \mathrm{H} / 950$. AlFarabi believes that the human body is composed of two entities; namely the body and soul. The former is limited by time and space, measurable and divisible, while the latter is different from all other qualities of the body. He accepts that the body belongs to the world of Creation, while the soul belongs to the super-sensible world (Sheikh, 1974: 173).

Furthermore, Al-Farabi also accepts, the soul cannot reach perfection while it stays in a nonliberated state in the body. It will only attain perfection and its greatest happiness once it is freed by the body during death (Al Ghazali 1873: 8-14, Umaruddin, 1991: 31). Al-Farabi expanded the boundaries of speculation prior to the consideration of human nature, the meaning of his life, his place in the universe, its role in society, the nature of the state association. As such, he needs the help and cooperation of others in the society for his survival and in his exertion towards a perfect life. Due to this fact, he stressed that an individual's relationship with others in this earthly life is a certain thing and he recognition of a certain common to mankind natural properties, they observed in a reasonable activity. He is of the opinion, there is a reason which led to the freedom of the human will, his ability to choose between good and evil, of the independence of his judgments, and his ability to improvement, the important role of knowledge in human society, about the bright future of mankind (Anar, 2015: 12). Ibn Sina (370-428H / 980-1037) known as Avicenna and also known as the Al-Shaykh al-Ra'îs (Sheikh, 1974: 34). He narrates the nature of human beings by applying terms which form spiritual features like; soul and intellect exchangeably to mean the spirit (Rahman, 1951: 116-120). Human soul emanates from tenth intelligence of the first being and is in a state of impermanency and will return back to original state through spiritual journey to unite with its original state of being. Henceforth, he is of the belief that the soul can live unconventionally without the body. Abu Hamid Muhammad Ibn Muhammad Ibn Muhammad Al-Ghazali or popularly known in the Islamic world as Imam Al-Ghazali $(450 \mathrm{H} / 1058-505 \mathrm{H} / 1111$ wrote his monumental book Ihyā' 'Ulū $m$ al-Dīn (Revival of the Religious Sciences). He dealt with many aspects of human Nafs (human Self) and elaborates many dimensions of human life pertaining to the physical and spiritual cleanliness, knowledge, worship, man-God relationship, man to man relationship, etc.

Ghazali very eloquently described the human nature which is considered his many contribution to human psychology. He is of the view that man occupies a position mid-way between the animals and angels while utilizing the mental consciousness for achieving the ends as per his determinism. He elucidates on this concept, that man has the capacity to rise to the level of the angels, when guided by acts of righteousness, and adequate knowledge which is inherent by him with spirit and at the same time he is correspondingly susceptible to fall to the lowest of low in his character and conduct while following to worldly desires and lavish activities and resembles like animals who have single motto of life to satisfy their self-indulgence. Ghazali strongly emphasis on the utilization of divine knowledge for successive end and to guide his nature for the human welfare and personality development (Umaruddin, 1991: 64). The psycho-spiritual development of the human soul, of Al-Ghazali, is contemporary form of personality development in modern 
psychology. His ideas on the personality development of man towards Insā $n$ Kā mil or Insā $n$ Sā lih (perfect man or righteous man) among others include the maintenance of a good mental health and spiritual training, also gives prescriptions of how to remedy many of these spiritual and psychological illnesses of human beings (Umaruddin, 1991: 45).

Al-Ghazali in areas of human nature and personality development, much of what is achieved in modern day psychology is to mainly explore and investigate the overt human behaviour without considering the fact from where human actions and behaviors emanate in the human body (Langgulung, 1981). With regards to human nature, Al-Ghazali expounds that man has four natures or attributes in him, namely;1) Beastly Nature 2) Animal Nature 3) Devilish Nature 4) Angelic Nature. He symbolically pronounces the human soul as a mirror that echoes the good or evil qualities of an individual. Acts of virtue make the soul gleam, dazzling and cheerful, while evil and sinful acts of an individual experience divine obscurity on the soul (Karim, Maulana, 1978: 3). In his opinion, the soul represents the actual human being, while the observable disposition of man is just the reflection of man's inner dimension. Al-Ghazali is of the opinion, that the human behaviour is the exact manifestation of one's inner well-being (Munawwar, 1985: 32). Ibn Rushd $(520 \mathrm{H} / 1126-595$ / 1198), one of the great Muslim philosophers of the middle ages, one of the functions of the human soul is that it acts as a driving force in order for the body to perform its varied activities. He also emphasizes the immortality of the human soul after death of the body. In the Tahafut, Ibn Rushd speaks of the soul as a faculty that comes to resemble the focus of its intention, and when its attention focuses more upon eternal and universal knowledge, it become more like the eternal and universal. As such, when the soul perfects itself, it becomes like our intellect. This, of course, has impact on Ibn Rushd's doctrine of the afterlife. This growth towards perfection in the hereafter is something that was not well elaborated by Ibn Rushd (Sheikh, 1974: 123). Abu Zaid Abd Rahman Ibn Muhammad Ibn Khaldun (732H / 1332-808H / 1406) a sociologist wrote extensively on the social nature of man. According to him, what distinguishes man from all other animals is his ability to think. The superiority of man over other living creatures is that he has the potentials to think, well-organize his ideas and to execute them in an orderly manner. Ibn Khaldun further believes that, man due to his thinking capacity, has been appointed as Allah's vicegerent on earth and for this reason everything else in this world becomes subservient to him. Another aspect of man that has been highlighted by Ibn Khaldun is that, man is gregarious by his nature. Therefore, he cannot live by himself. His existence is only possible when he lives a life in association with other fellow human beings (Khaldun, 1986: 34).

Large number of psychologists wrote on human nature are in consonance that personality is characterized by individual's passion and consistency throughout time but vary in their views about the concept of individuality and universality as innate human nature. Psychologists like Freud, Jung Adler, Fromm, All-port, Roger and Maslow have variation of opinion on the individual and universal character of human beings, some of the them consider it stage development from individual to universal like Jung, while as Maslow believes that needs are common among people but are satisfied by different ways. So, psychologists believe that distinctiveness is the basic quality of human nature and personality because individuals vary from each other by having different capacities of learning (Achoui, n.d: 91).

\section{CONCLUSION}

Education and philosophy of education based on the behaviourist concept of human nature most probably had and will fail to produce men who are emotionally, spiritually and morally strong for the reason that these human qualities are not emphasized in the behaviourist concept of man. Furthermore, Individuals educated on the behaviourist concept of human nature will lack the many 
qualities which are exclusively human, like true love, empathy, sympathy, kindness, generosity, feeling of fraternity, etc. Therefore, the application of the behaviourist concept of human nature will most likely produce an individual who is not morally and socially responsible towards the environment and humanity. The production of such an individual is mainly due to the reason that his spiritual and emotional developments were not given the due consideration. Many Muslim scholars have for a long time ignored the study of human nature despite the importance of this discipline in the development of civilization and even that man is the center of the Qur'anic message as being considered as vicegerent of Allah on the earth. The molding of Human behaviour as per his fitrah is very important in order to overcome the colonial approach and unjust manner of the great powers. If human civilization wants to achieve peace and wish to be psychologically balanced they need to behave as per their innate nature upon which they are created. Large portion of the Qur'an speaks about the creation of human beings from single soul and with same fitrah. The Islamic view emphasizes upon the importance of growth, change and learning in the formation of personality and behaviour of human beings to relive humanity from tension and chaos and disturbance. 


\section{References}

Achoui, Mustapha, (n.d). Human Nature from a comparative psychological Perspective, American Journal of Islamic Social Sciences, V.15, Issue.4.

Al-Ghazali. (1873). The Alchemy of Happiness, by Mohammed Al-Ghazzali, the Mohammedan Philosopher, trans. Henry A. Homes, Albany, N.Y.: Mansell.

Al-Attas, S.M.N. (1985). Islam, Secularism and the Philosophy of the Future, London: Mansell Publishing Limited.

Al-Isfahânî, al-Raghîb. (1984). Mu'jam Mufradat Alfaz al-Qur'ân ed. Nadîm Mar'ashlî. (Dârul Karîb al-'Arabi.

Al-Maududi, Seyyed Abu A'la. (1992). The meaning of the Qur'an (7th edn.). Lahore: Islamic Publication (PVT) Limited

Al-Qur'ān, al-Tīn: 4, Ali, Abdullah Yusuf. (1989). The Holy Qur'an: Text, translation and commentary. Maryland: Amana Corporation.

Al-Sharîf, Jurjânî, Alî ibn Muhammad al-Sayyad, (1991). Kitâb al-Ta'rifat ed. 'Abdul Mun'îm alHafani. Cairo: Dârul Rashad.

Ali, Abdullah Yusuf. (1989).

Allamah, Sayyid Muhammad Husayn at-Tabataba'i. (n.d.). Islam and the Contemporary Man, ABWA Publishing and Printing Center.

Anar, Tanabayeva, et-al, Al-Farabi's. (2015). Humanistic Principles and "Virtuous City, The European Proceedings of Social \& Behavioural Sciences, icCSBs 2015 January, Al-Farabi Kazakh National University, av. Al-Farabi, 71, Almaty, 050004, Kazakhstan, 12.

Ansari, Zafar Afaq (ed). (1992). Qur'anic concepts of human psyche, International Institute of Islamic Thought, Islamabad.

Ansari, Zafar Afaq (ed). (1992). Qur'anic concepts of human psyche.

Asad, Muhammad. (1980). The Message of The Quran, Dar Al-Andalus Gibraltar.

Atiyeh, G. N. (1985). Al-Kindi: The philosopher of the Arabs, Islamic Research Institute, Islamabad.

Fazlul-Karim, Al-Haj Maulana. (1978). Imam Ghazzali's Ihya Ulum-id-Din. Book 3, Sind Sagar Academy, Sind.

Geisler, Norman \& Saleeb, Abdul. (2002). Answering Islam: The Crescent in Light of the Cross 2nd ed.; Grand Rapids, Mich.: Baker Books.

Hunt, Morton. (1994). The story of psychology, Anchor Books, New York. 
Ibn Manzûr, (n.d.). Lisân al-'Arab al-Muhît.

Ibn Taymîyya Dar'u Ta'arud al 'Aql wa al Naql. (1981). Vol. 8, ed. Muhammad Rashad Sa'im. Riyadh: Jami'at al-Imâm Muhammad ibn Sa'ud al-Islamiyyah.

Izzati, Abu al-Fazl. (2002). Islam and Natural Law, Islamic College for Advanced Studies Press.

Saliba, Jamil. (1971). al-Mucjam al-Falsafiyy bi al-Anșāri (t.t.), Lisan al-cArab. T.t.p: Dār alMisriyyah Li al-Ta'elif wa al-Tarjamah.

Kamus al-Munjid fi al-Lughah al-cArabiyyah al-Mucāsirah (2000), Beirut: Dār al-Musyrif.

Kamus Dewan. (1996). Third Ed. Kuala Lumpur: Dewan Bahasa dan Pustaka.

Khaldun, Ibn. (1986). The Muqaddimah. Trans. Franz, R. 3rd edition. Vol. 2. Routledge and Kegan Paul, London.

Lane, E. W. (1972). Arabic-English Lexicon. 2 volumes, Cambridge: The Islamic Texts Society.

Langgulung, Hasan. (1981). The Ummatic paradigm of Psychology. Paper presented at the International Seminar on Islamic Philosophy and Science, University Sains, Malaysia, Penang, 30th May-2nd June.

Manzûr, Ibn. (1988). Lisân al-'Arab al-Muhît. Vol. 4, ed. A. al-'Alayali, (beirut: Dâru Lisân al-'Arab.

Mohd Abbas. (1997). Human nature: A comparative study between western and Islamic psychology. Kuala Lumpur: International Islamic University Malaysia.

Munawwar. (1985). Iqbal and Quranic wisdom. (2nd.edn.) Lahore: Iqbal Academy Pakistan., p.32

Musa, M.Y. (1953). Falsafah al-Akhlaq fi al-Islām. Cairo: Maktabā wa-Matbaea Muhammad cAli Subayh wa-Awladūh.

Pasnau, Robert, ed. \& trans. (2002). The Cambridge Translations of Medieval Philosophical Texts. Vol. 3: Mind and Knowledge, Cambridge University Press, Cambridge.

Qadir, C. A. (1991). Philosophy and science in the Islamic world. London: Rutledge.

Qutb, Muhammad. (1983). Dirasat fi al Nafs al insiniyah, Darul Shuruq, Bairut.

Rahman, Fazlur. (1988). Muhammad: Encyclopedia of Seerah. Vol. 6. London: Seerah Foundation.

Rahman, Fazlur. (1951). Avicenna's psychology. Westport Connecticut: Hyperion Press Ins.

Razak, Mohd Abbas Abdul. (1997). Human Nature: A Comparative Study between Western and Islamic Psychology Kuala Lumpur: IIUM.

Sharh Fiqh al-Akbar li-Abī Hanīfah al-Nu'mā n, ed. by al-Shaykh Marwān Muhummad al-Sha"ār, 1st edn. (1997). Dār al-Nafā’is, Beirut. 
Sheikh. (1974). Studies in Muslim philosophy. Lahore: SH. Muhammad Ashraf.

Qutb, Sayyid. (1979). Fizilal al Qur'an, Darul-Shuruq, Bairut: Vol 6.

This repetition also applies to the $7^{\text {th }}$ form verb infatara, $5^{\text {th }}$ form tafattara and the $1^{\text {st }}$ form fatara, e.g. idha's-samâ'unfatarat 'When the heaven shall be cleft', (Qur'ân 82:1), and yakadu'ssamâwâtu yatafttarna minhu 'The heavens almost become repeatedly rent in consequence thereof, (Qur'an 19:92), and tafatarat qadamahu 'his feet became cracked'.

Umaruddin, M. (1991). The ethical philosophy of al-Ghazzali. Lahore: SH. Muhammad Ashraf. 
Human Psychology (fitrah) from Islamic Perspective 